\title{
X-Box Binding Protein 1
}

National Cancer Institute

\section{Source}

National Cancer Institute. X-Box Binding Protein 1. NCI Thesaurus. Code C71448.

X-box binding protein 1 (261 aa, $\sim 29 \mathrm{kDa}$ ) is encoded by the human XBP1 gene. This protein is a bZIP transcription factor that is involved in both the transcription of major histocompatibilty complex class II genes and the response to unfolded proteins and viral infection. 